\title{
HYPERAMMONEMIA: AN UNUSUAL PRESENTING FEATURE OF MULTIPLE MYELOMA
}

\author{
A. S. SHAH, N. SHETTY, S. JAISWAL, B. C. MEHTA
}

\section{ABSTRACT}

\begin{abstract}
A 76 year old lady presented with altered sensorium and was found to have hyperammonemia on evaluation. She had no evidence of liver disease. For her symptomatology of backache, evaluation by bone marrow study showed evidence of multiple myeloma. She was given chemotherapy for multiple myeloma, which resulted in improvement in her sensorium, alongwith this there was also a rapid decline in serum ammonia levels. Hyperviscosity and hypercalcemia are common causes of altered sensorium in a patient with myeloma but in this case hyperammonemia was the likely cause.
\end{abstract}

Key Words: Hypercalcemia, hyperviscosity, sensorium

\section{INTRODUCTION}

Hyperammonemia is commonly seen in liver disease, Reye's syndrome, inborn errors of urea synthesis, severe urinary tract infections and induced by medications like valproate. ${ }^{[1]}$ We had a patient who presented with disturbance of consciousness and flapping tremors. She was diagnosed to have hyperammomnemia and multiple myeloma and there was a dramatic improvement in sensorium on treating her for myeloma with chemotherapy which paralleled the rapid decline in serum ammonia levels.

\section{CASE REPORT}

A 76 year old lady was admitted with fever and

Department of Hematology, BSES MG Hospital, Mumbai, India

Correspondance: altered sensorium gradually worsening over past 3 weeks. A day prior to admission she had a fall and was unable to move right leg. She had backache since past 8 months for which she was evaluated by an orthopedic surgeon. $\mathrm{MRI}$ of the dorso-lumbar spine done at that time showed compression fracture of the second lumbar vertebra, degenerative changes at multiple levels and bone marrow edema. She was advised bed rest and treated with analgesics and Taylor's brace. There was only partial relief with these measures. About 3 months back she was evaluated for generalized weakness, persistent backache, difficulty in walking, loss of appetite and intermittent irrelevant talks. Her investigations at that time were: hemoglobin $8.3 \mathrm{~g} / \mathrm{dL}$, white cell count $6800 / \mathrm{cmm}$, platelet count $110,000 /$

B. C. Mehta, Smt. S. C. Mehta, Hematology Department, BSES MG Hospital, S. V. Road, Andheri (west), Mumbai 400058, India. E-mail: labmed@ghrc-bk.org 
$\mathrm{cmm}$, erythrocyte sedimentation rate of 142 $\mathrm{mm}$ at the end of $1 \mathrm{st}$ hour, blood urea nitrogen $26 \mathrm{mg} / \mathrm{dL}$, creatinine $3.18 \mathrm{mg} / \mathrm{dL}$ and urine examination showing 10-12 pus cells per high power field. She was treated with antibiotics, vitamin and calcium supplements but symptoms of backache and weakness showed only minimal improvement. She had no history of hypertension, diabetes, ischemic heart disease, tuberculosis or any other major illness in the past. She had undergone surgery for $L 4$ - L5 disc prolapse 20 years back.

On examination, she was in altered sensorium, talking irrelevantly, temperature 100.6 F, pulse rate of 88 per minute, blood pressure $130 / 90 \mathrm{mmHg}$ and respiratory rate of $28 / \mathrm{min}$. She was pale and had flapping tremors. There was no lymphadenopathy, icterus, petechiae or other signs of liver cell failure. There was pain on trying to move the right leg and tenderness over the right greater trochanter. Examination of her respiratory and cardiovascular system was normal. There were no dilated veins over abdomen, hepatosplenomegaly or ascites and bowel sounds were normal. Nervous system examination revealed terminal neck stiffness but there was no focal neurological deficit and both the plantars were extensors.

Her present investigations were as follows: hemoglobin $7.5 \mathrm{gm} / \mathrm{dL}$, white cell count $21,000 / \mathrm{cmm}$, differential count showed $77 \%$ neutrophils, $20 \%$ lymphocytes, $2 \%$ monocytes and $1 \%$ plasma cells. The peripheral blood smear examination revealed increased rouleaux formation. Erythrocyte sedimentation rate was $153 \mathrm{~mm}$ at the end of $1^{\text {st }}$ hour, blood urea nitrogen $40 \mathrm{mg} / \mathrm{dL}$ and creatinine $3.5 \mathrm{mg} /$
$\mathrm{dL}$, total bilirubin was $0.8 \mathrm{mg} / \mathrm{dL}$ (direct 0.45 and indirect $3.5 \mathrm{mg} / \mathrm{dL}$ ), SGOT of $16 \mathrm{IU} / \mathrm{L}$ and SGPT of $20 \mathrm{IU} / \mathrm{L}$, Total protein of $5.8 \mathrm{~g} / \mathrm{dL}$, albumin $2.8 \mathrm{~g} / \mathrm{dL}$ and globulin $3.0 \mathrm{~g} / \mathrm{dL}$. Serum ammonia was $310 \mathrm{ig} / \mathrm{dL}$, serum calcium of $13.2 \mathrm{mg} / \mathrm{dL}$. X-ray of the hip showed fracture of the right neck of femur. Her CT scan brain and cerebrospinal fluid examination revealed no abnormality. Protein electrophoresis showed presence of monoclonal band in the $\mu 2$ globulin region with level of $\mu 2$ globulin being $31 \%$ of total proteins and suppression of beta and gammaglobulin. Bone marrow examination revealed $20 \%$ plasma cells with binucleate forms. $X$ ray of the pelvis showed pathological fracture of the neck of right femur, however $X$ ray of the skull did not reveal lytic lesions. There was no evidence of BenceJones proteinuria and â2-microglobulin was 4 $\mathrm{mg} / \mathrm{L}$. Thus the patient was diagnosed to have multiple myeloma, stage III. ${ }^{[2]}$ She was treated with melphalan $10 \mathrm{mg} /$ day and prednisolone $60 \mathrm{mg} /$ day for 4 days. ${ }^{[3]}$ In addition she also received intravenous infusion of pamidronate once a month and supportive care. There was a remarkable improvement in level of sensorium and serum ammonia levels also reduced to normal levels within 5 days.

Presently she has completed 3 cycles of melphalan and prednisolone and is doing well.

\section{DISCUSSION}

This patient presented with disturbance of consciousness and had clinical features suggestive of encephalopathy. She had multiple myeloma, probably since a year, which was not diagnosed till the present admission. She had hyperammonemia which could explain the disturbance of consciousness; but no evidence of liver disease or other disorders commonly associated with high ammonia levels. Hyperviscosity and hypercalcemia, commonly associated with multiple myeloma, are causes of altered sensorium in some patients. The remarkable improvement in our patient's consciousness along with fall in ammonia level in blood with only therapy for myeloma shows that hyperammonemia was indeed due to myeloma itself. The patient also had hypercalcemia, which could be a contributing factor to disturbance of consciousness but improvement in consciousness correlated very well with decline in serum ammonia.

Reference to literature revealed mention of hyperammonemia in multiple myeloma ${ }^{[4]}$ and further search revealed few case reports of hyperammonemia in myeloma. ${ }^{[1,4-7]}$ Matsuzaki et al evaluated serum levels of ammonia and amino acids in 85 patients with multiple myeloma and demonstrated hyperammonemia in six of them. ${ }^{[5]}$ None of them had liver cell failure or any other known causes of hyperammonemia. All the six patients also showed serum amino acid disturbances in various degrees which were strikingly different from those seen in hyperammonemia of liver cell failure. These observations provide evidence to the existence of a peculiar amino acid metabolism in myeloma cells causing hyperammonemia.

Fujii et al have evaluated autopsy findings in four patients of myeloma and hyperammonemia and only one of them was found to have liver dysfunction with severe infiltration of liver parenchyma by myeloma cells, but all had disturbances in amino acid metabolism. ${ }^{[6]}$

Matsuzaki et al have reported a patient with myeloma who developed hyperammonemia during the course of treatment of myeloma. ${ }^{[1]}$ Myeloma cells were isolated and cultured and were demonstrated to secrete ammonia. Otsuki et al have also demonstrated ammonia production by myeloma cells in vitro. ${ }^{[7]}$

Our case and review of literature suggests an association between multiple myeloma and hyperammonemia and we recommend that serum ammonia should always be monitored in any patient of myeloma with disturbance of consciousness.

It is also interesting to note that majority of case of hyperammonemia with myeloma reported in literature are from Japan and not from western countries, probably suggesting regional or racial differences in amino acid metabolism which leads to ammonia production. This requires further studies to confirm.

\section{REFERENCES}

1. Matsuzaki H, Uchida M, Yoshimura K, Yoshida $\mathrm{M}$, Akahoshi $\mathrm{Y}$, Okazaki $\mathrm{K}$, et al. Hyperammonemia in multiple myeloma. Acta Hematol 1990;84:130-4

2. Durie $B$, Salmon $S$. A clinical staging system for multiple myeloma. Cancer 1975;36:842

3. Bergsagel DE, Sprague CC, Austin C, Griffith KM. Evaluation of new chemotherapeutic agents in the treatment of multiple myeloma IV:I- phenylalanine mustard. Cancer Chemother Rev 1962;21:87. 
4. Lokhorst $\mathrm{H}$. Clinical features and diagnostic criteria. In: Jayesh Mehta and Seema Singhal, Ed. Myeloma. London: Martin Dunitz Ltd.; 2002. p. 151-68.

5. Matsuzaki $\mathrm{H}$, Hata $\mathrm{H}$, Sonoki $\mathrm{T}$, Matsuno $\mathrm{F}$, Kuribayashi N, Yoshida M, et al. Serum amino acid disturbance in multiple myeloma with hyperammonemia. Int J Hematol 1995;6:131-7.
6. Fujii S, Fukuda S, Sezaki T, Murakami M. Clinicopathological study of multiple myeloma associated with hyperammonemia. Rinsho Ketsueki 1998;39:27-33.

7. Otsuki T, Yamada O, Sakaguchi H, Ichiki T, Kouguchi $\mathrm{K}$, Wada $\mathrm{H}$, et al. In vitro excess ammonia production in human myeloma cell lines. Leukemia 1998;12:1149-58.

\section{Indian Journal of Medical Sciences is pleased to announce the launch of its website. The URL of the website is http://www.indianjmedsci.org.}

The features of the site are:

- Free full text availability of articles in HTML as well as PDF

- Direct link to abstracts and full text from the cited references

- Direct link to PubMed abstracts of published by authors from left hand side navigation links (Resource Links) on the full text article pages.

- Link from text of articles to various databases and search engines

- Facility to submit comments on articles

- Email notifications on new issue release

- Statistics of articles download and visits

- Structure based on OpenURL, DC Metadata and other international standards 